\title{
Fang, Xudong 方旭東, The Painting Comes After the Plain Groundwork: The Interpretations and Philosophical Studies of the Classics 繪事後素: 經典解釋與哲學研究
}

\author{
Beijing 北京: Peking University Press 北京大學出版社, \\ $2012,8+206$ page
}

\section{LIU Zengguang}

FANG Xudong's new book, The Painting Comes After the Plain Groundwork: The Interpretations and Philosophical Studies of the Classics 繪事後素: 經典解釋與哲學研 究, emphasizes two aspects of Confucianism, the interpretation of the Confucian classics and their philosophical study, which is why he accordingly divided the book's content into two parts. However, the two parts cannot be seen as totally unrelated, because, especially for Chinese philosophy or Chinese thought, the philosophical study of the classics is often contained in the interpretation of the classics, or we can say the latter is the basis of the former.

Fang gave this book an impressive title. As is well known, in the Analects 論語 Confucius said: "The painting comes after the plain groundwork" (Analects 3.8) while discussing the meaning of a poem in the Classic of Poetry (shijing 詩經) with Zixia 子夏, one of his brilliant disciples. The title summarizes the contents beautifully, given its two separate parts. In "Interpretation of Confucian Classics," Fang mainly analyzes the ancient commentaries on the Confucian classics and then makes judgments of his own on the different interpretations from these commentaries. In "Philosophical Studies of the Confucian Classics," his major work is handling philosophical problems contained in the ancient Confucian classics. Therefore, the relation between the two parts exactly corresponds to that of the painting ( $h u i$ 繪) and the plain groundwork ( $s u$ 素).

Each part of the book has 6 articles. There is an additional article concerning Chinese hermeneutics as an appendix, which is also closely related to the book's intention. Especially in the second part, Fang's skillful and manifold uses of the methods of textual dissection and philosophical elucidation often offer a new perspective and insight through an apparently small point. It is impossible for me to introduce every article at great length in this short review. I will try to discuss some chapters in order to show the spirit of the book instead of offering a comprehensive overview.

In the first part, Fang focuses on how to understand the classical interpretations made by past Confucians. It is well known that the Four Books became the Confucian canons

Liv Zengguang $(\bowtie)$

School of Philosophy, Fudan University, 200 Handan Road, Shanghai 200433, China

e-mail: zengguang.liu@gmail.com 
in the Song Dynasty after ZHU Xi 朱喜 composed the Collected Commentaries of the Four Books (Sishu Zhangju Jizhu 四書章句集注). Fang compares the interpretations of the Four Books presented in Neo-Confucianism during the Song Dynasty (Songxue 宋 學) with those of the “classicist” school (Hanxue 漢學) and points out that there existed a kind of difference of over-interpretation and under-interpretation between the two types. Both types have advantages and disadvantages, and the traditional view that considered the Han school superior to the Song school on classical interpretations is not right. An example of the over-interpretation made by the Song school is expressed in their understanding of the different descriptions of the "benevolence and loyalty" (zhongshu 忠恕) respectively in the Analects and the Doctrine of the Mean. For the sake of integrating the two different descriptions, some of ZHU Xi's interpretation works could be seen as a misreading, but at the same time, the Song school expanded the implications of the original Confucianism through misreading.

Generally speaking, to some extent, the approach of classical interpretations made by the Song school can be called "interpreting the classics according to the Heavenly principle" (yili jiejing 以理解經) and the approach of the Han school can be roughly called "interpreting the classics with other classics" or "letting the classics interpret themselves" (yijing jiejing 以經解經). But in the fifth article, Fang points out the fact that the Song school also used the Book of Changes to interpret the Mengzi, and compares HUANG Zongxi's 黃宗羲 (1610-1695) and JIAO Xun's 焦循 (1763-1820) interpretations of the classics, showing that these different methods can be good or bad, given different contexts.

In the second part, Fang tries to reveal philosophical insights contained in the traditional Chinese texts in many subfields of philosophy, such as political philosophy, moral philosophy, epistemology, and even the philosophy of ecology. In recent years, studies on the newly excavated documents have became a hot spot, and Fang has worked in this area, which can be seen in the seventh article: "A Study of the Morality as the True Color of Confucius's Political Philosophy." In this article, he makes detailed analysis into the “min zhi fumu 民之父母” (the parents of the common people), indicating that in this document Confucius emphasized the idea that the monarch should rule by both rituals and music, but only if the monarch embodied virtues could he transcend formalized rituals and music so as to become an ideal ruler who is just like parents of the common people. This is a very appropriate interpretation of Confucian political philosophy with respect to the relationship between the monarch and the common people.

In the tenth article "Obedience or Disobedience: Mengzi on the Political Obligation of the Subjects," Fang discusses another issue in Confucian political philosophy concerning the relationship between the monarch and the subjects implied in the Mengzi. In the view of the Mengzi, subjects could say no when summoned by their monarch. This seemed incredible in ancient China, but it was very reasonable for Mengzi, because he thought the relationship between monarch and subjects was constructed on the basis of contracts, so subjects had an obligation to work for the monarch and accept the grain for rations granted by him, but once the subjects could not fulfill their duties successfully, they could refuse the grain for rations, and not work for the monarch any more on their own initiative. That means the subjects had the political right of unilateral termination of a contract. Fang's analysis inspires us to understand the ancient Chinese resources more deeply and observe them with a new and even modern perspective at times. 
The eighth and ninth articles discuss Confucian moral philosophy. In the eighth article, Fang investigates the principles of benevolence and loyalty promoted by Confucianism. He notes that in the Doctrine of the Mean it is said that "the gentlemen governed the common people in the way of the common people" and argued that this means that we should treat other people in the way of other people. This proposition is better than "put oneself in anther's position," because the latter has an implication that we can impose our opinion on others. At last, Fang concludes that treating other people in the way appropriate to other people is a proposition that is more applicable to modern society. After all, pluralism of values has become the most apparent feature of the modern society. In the ninth article, "Why Doing Good is not an Energeia but a Dunamis," Fang explores the issue of moral will in Xunzi 萌子. Energeia and dunamis are words in Aristotle's philosophy which mean potentiality and actuality, respectively. In the viewpoint of Xunzi, every one had the potential to become a sage, but in reality they did not. Xunzi argues that this is because they did not will and desire to do so. Therefore, in the moral philosophy of Xunzi, the moral will or moral desire played a key role in the process of personal transformation into goodness from badness.

With respect to Confucian epistemology, Fang analyzed one phrase in the Analects, "it is the benevolent man alone who can like or dislike other men," in the eleventh article, "Is There Right or Wrong in Liking and Disliking Someone?" The interpretations of the School of Principle (lixue 理學) represented by ZHU Xi held that the liking or the disliking of someone meant to like or dislike according to Heavenly Principle (tian li 天理), and the benevolent men (ren zhe 仁者) liked or disliked the right way due to his selflessness. On the other hand, the interpretations of the Classicist School (Han xue 漢學) held that the liking or the disliking of someone meant liking or disliking in the way the majority of the people do. The issue, then, is about the criterion of correctness and wrongness. Roughly, "Principle" ( $l i$ 理) stands for a kind of universal value which transcends any special community, while the uniformity (tong 同) of liking and disliking stands for a kind of particular value of special community. The doctrine which took Heavenly Principle (tian li) as the criterion of correctness and wrongness is close to the correspondence theory of truth, while the doctrine which takes uniformity (tong) as the criterion is close to conventionalism.

We can notice that Fang borrowed some Western philosophical terms to analyze and interpret the ancient Confucian Classics. This is indispensable and necessary for Chinese scholars today who work on "Chinese philosophy," just as many scholars are keen on making use of phenomenology to interpret "Chinese philosophy" at this moment. Since the later half of the Ming Dynasty, Chinese culture has been influenced by Western culture, and a famous Chinese philosopher of the last century, FENG Youlan 馮友蘭 (1895-1990), commented that we are still in an era affected by Western thought, which means that we still need to absorb Western thought. This situation is under change. Fang's book shows a new trend of studies of Chinese philosophy, as he writes in the preface: "a good philosophical interpretation is such a kind of interpretation: it can make the text of old documents endowed with new meaning, and the meaning is certainly not groundless; on the contrary, it is deeply rooted in the text."

Open Access This article is distributed under the terms of the Creative Commons Attribution License which permits any use, distribution, and reproduction in any medium, provided the original author(s) and the source are credited. 